\title{
The Coke Dry Quenching Process as Energy-saving Technology*
}

\section{By Takashi MORI,** Takeo FUJIMURA** and Seiichiro SATO**}

\begin{abstract}
Synopsis
Nippon Kokan K. K. (NKK) undertook the so-called "Ogishima Project" in 1969 with a view to replacing the obsolete steel-making facilities at its Keihin Works with the modern facilities of a new steel-making base to be constructed on Ogishima, a newly developed green steel works on the sea near the Keihin Works. Fortunately, start-up and operation of the new C.D.Q. plant was successful. Operational data from the C.D.Q. plant are reported here with an evaluation of the energy-saving effect of the C.D.Q. process. The NKK-Licensintorg C.D.Q. plant is now exhibiting high operational stability in coke quenching and good energy-saving performance.
\end{abstract}

\section{Introduction}

The Ambitious Ogishima Project of NKK, with provision for construction of a new steel-making base to completely replace the obsolete facilities of the colossus Keihin Works, exploits all modern technologies of rationalization and environmental protection to the full. Stage 1 work was completed in the autumn of 1976, and currently, stage 2 work is underway. In the project, among other priority items particular emphasis was given to energy-saving, and a target was set to reduce the previous energy consumption rate of 6.5 million kcal per ton of crude steel to 5 million kcal by the time of the completion of the project through an integrated energy control system.

Towards achieving this goal, many energy-saving technologies are being utilized, and the "utilization of the sensible heat of the red-hot coke" in the form of coke dry quenching (in this report to be referred to as C.D.Q.) plant had been adopted as a representative energy-saving technology. This plant has been operating with very favorable conditions.

In a steel-making works, normally, $400 \sim 500 \mathrm{~kg}$ of coke is consumed to produce a unit ton of pig iron. For example, in a blast furnace producing $10000 \mathrm{t}$ of pig iron daily, $4000 \sim 4500 \mathrm{t}$ of coke is consumed every day. Assuming an average coke yield and lump coke yield usable in blast furnaces being $76 \%$ and $64 \%$ of charged coal respectively, between 4750 and $5330 \mathrm{t}$ of red-hot coke must be produced by coke ovens every day. A rough calculation shows that the sensible heat possessed by this huge amount of coke is as much as $1.9 \times 10^{9} \mathrm{kcal} / \mathrm{d}$. Conventionally, the coke produced in coke ovens, in a red-hot condition at approx. $1000^{\circ} \mathrm{C}$ is quenched by water spray before use in blast furnaces, dissipating all the sensible heat of the $1000^{\circ} \mathrm{C}$ coke as hot steam into the atmosphere. The C.D.Q. technology retrieves this heat by heatexchangers and produces steam or electric power for energy utilization.

Historically, C.D.Q. technology was used in Europe in the early days of the coke-making industry, and it was also partly used before in Japan, but its use had been discontinued due to its disadvantages in economy, operation, and safety, and the water spray quenching method has found general use almost all over the world.

However, in 1960, a new C.D.Q. system characterized by large plant capacity and stable steam production was developed in the USSR on the basis of the earlier European C.D.Q. system with improvements. During the planning stage of the Ogishima Project, C.D.Q. was taken up as an important theme, and a series of surveys conducted in the USSR and other European countries in $1971 \sim 72$ revealed that the USSR type C.D.Q. system was superior to other systems with respect to process capacity, stability of steam production, and automatic operation; and that 28 C.D.Q. plants were in operation in 7 works in the USSR as of 1971, with a further 24 plants under construction, and all future iron works being scheduled to incorporate C.D.Q. plants. The fact that 7 th and 8th coke oven batteries of 130 ovens in total at Cherepovets steel works commissioned in 1972 are equipped with a 5-chamber coke dry quenching plant without a stand-by wet quenching stimulates the interest to the coke dry quenching technology. From these findings, the USSR type C.D.Q. system was considered to be fully practically operational. On the basis of these findings and further survey results, finally, a decision was made to adopt the C.D.Q. system for the No. 1 coke oven of the Ogishima Works. As

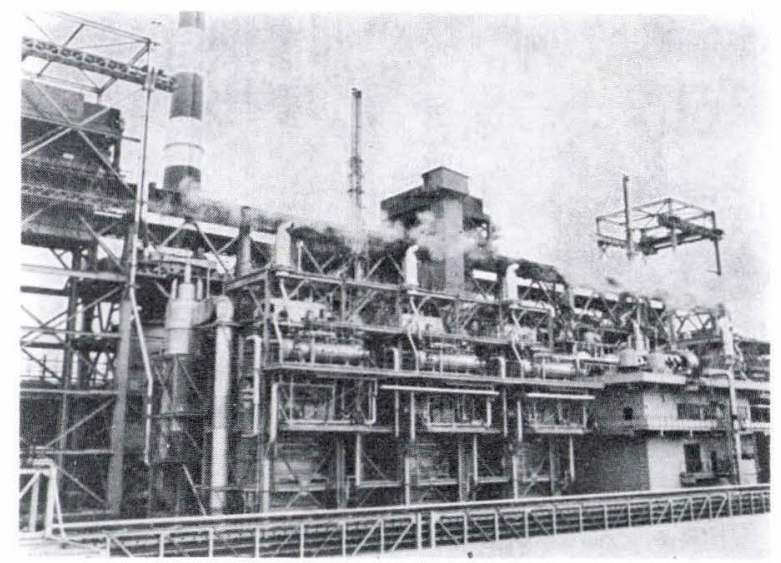

Photo. 1. General view of the C.D.Q. plant.

* Originally published in Tetsu-to-Hagané, 64 (1977), No. 13, Special Issue on Energy Conservation in Steel Industry, 1914, in Japanese. English version received April 16, 1979.

** Keihin Works, Nippon Kokan K. K., Minamiwatarida-cho, Kawasaki-ku, Kawasaki 210. 
the No. 1 coke oven of the Ogishima Works was a large oven, $7.55 \mathrm{~m}$ in height, incorporating 124 chambers of $52.5 \mathrm{~m}^{3}$ effective volume, NKK-Licensintorg C.D.Q. plant was so designed as to fully match the large volume of the coke oven, incorporating automatic control, environmental protection, and other improvements, and started operation in September 1976 simultaneously with the coke oven. During the one and half year since start-up, the C.D.Q. plant has been operating very stably, fully performing its expected functions as a coke quenching facility and an energy-saving facility. (Photos. 1 and 2)

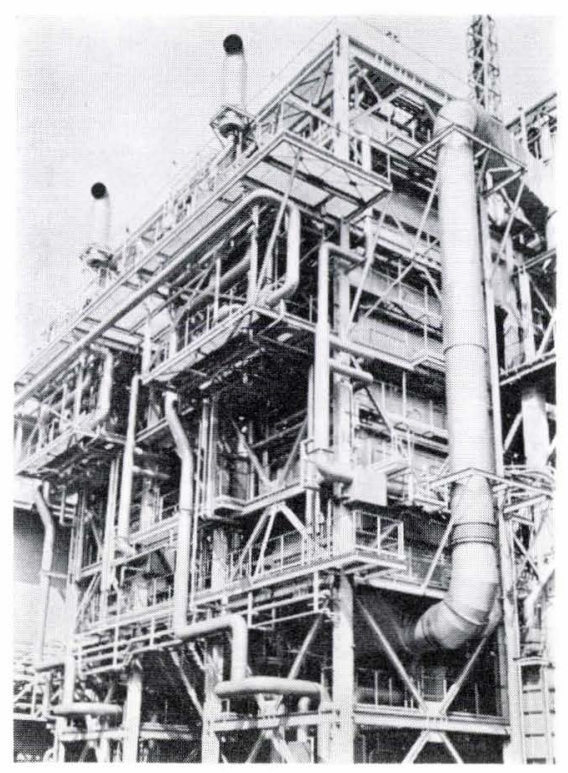

Photo. 2. View of the boiler.

\section{Outline of C. D. Q. Plant Facilities}

The C.D.Q. plant consists mainly of the following facilities :

1) A red-hot coke transporting facility to the quenching chamber

2) a quenching chamber

3) a cooled coke discharging facility

4) an inert gas recycling facility

5) a heat recovery boiler

6) a dust-collection and coke dust treatment facility.

Referring to the flow chart shown in Fig. 1, the red-hot coke pushed out from the coke oven is first charged through coke guide into the coke bucket on the coke car, then transported to the bottom of the crane tower, where, coke bucket is hoisted to the top of the tower by the $80 \mathrm{t}$ tower crane. The coke bucket runs horizontally to a position above the prechamber, where the bottom gate of the bucket opens to let the red-hot coke fall into the prechamber. The redhot coke gradually descends from the prechamber to the quenching chamber where the red-hot coke is cooled to below $200^{\circ} \mathrm{C}$ through contact with counterflowing cooling gas circulating in a closed system. At the bottom of the quenching chamber, there are a pair of coke discharging gates, and a sealed hopper provided with a double trap designed for gas-tight operation. They operate alternately to discharge the coke onto the belt conveyor. The circulating gas is blown into the quenching chamber at the bottom, exchanges heat with the hot coke while ascending in the quenching chamber, and, after having the coarse dust removed in the dust collector, enters the heat recovery boiler at approx. $800^{\circ} \mathrm{C}$. In the boiler, the sensible heat of this gas is recovered to produce steam with a

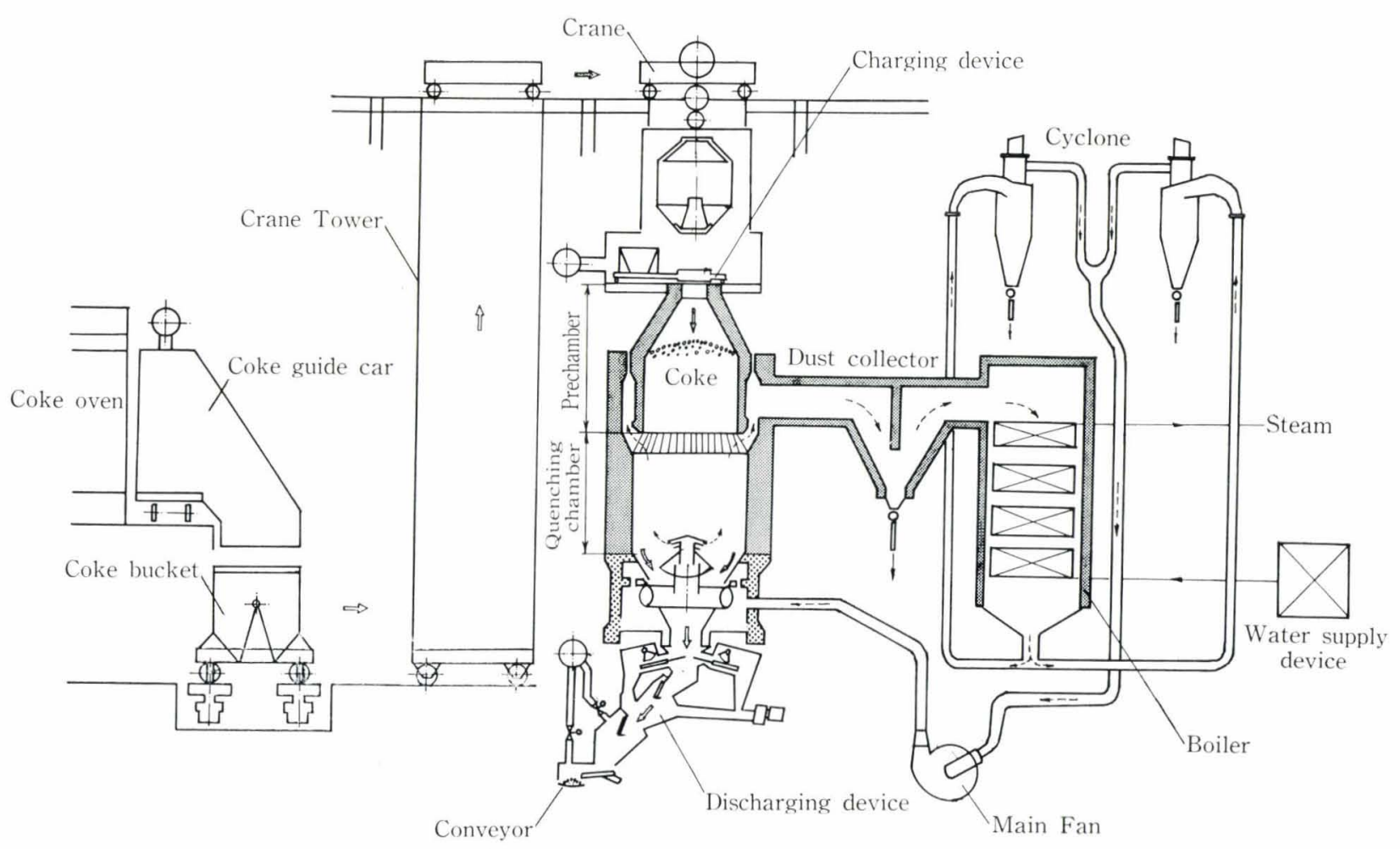

Fig. 1. Flowsheet of the C.D.Q. plant. 


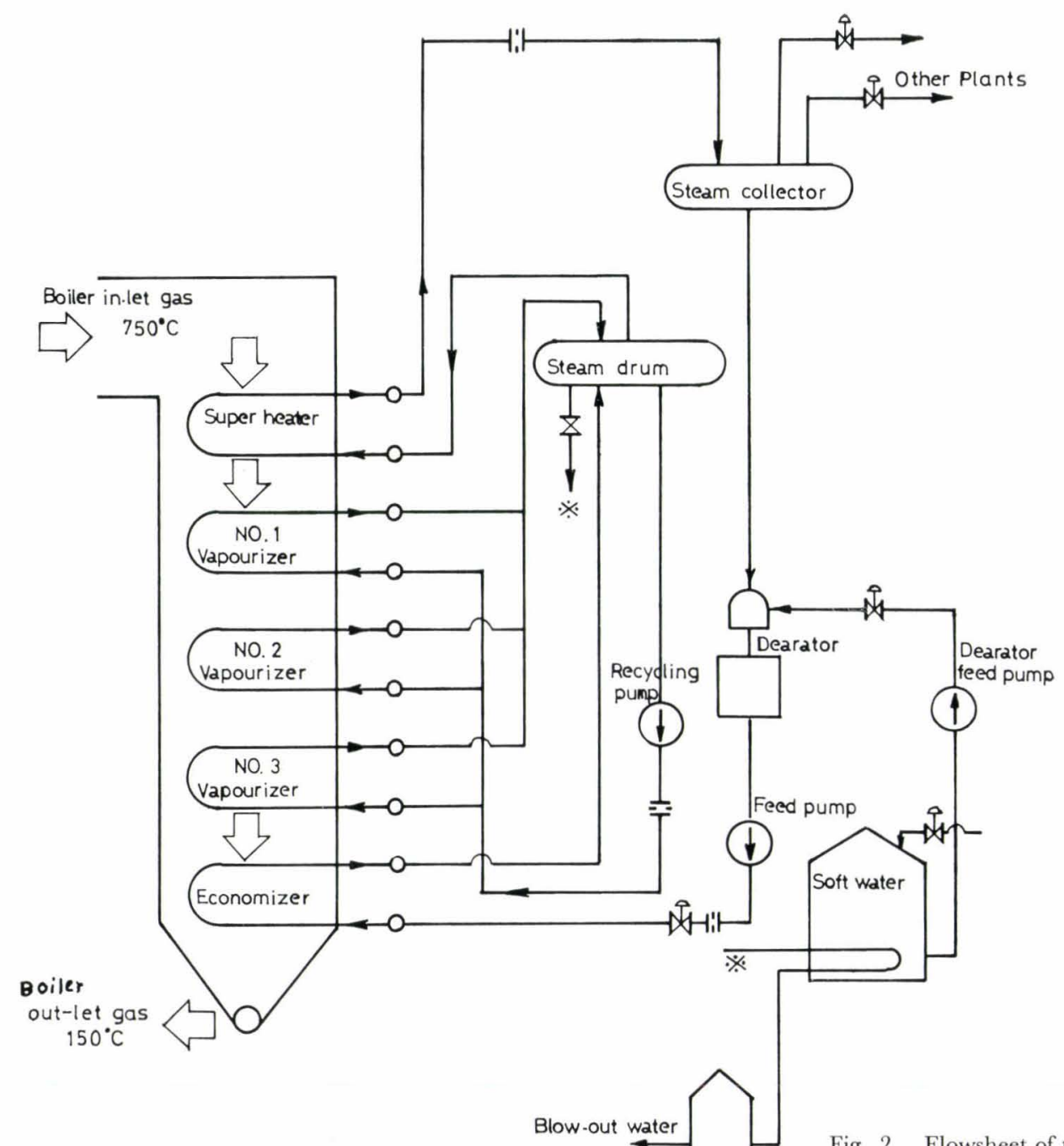

Fig. 2. Flowsheet of the C.D.Q. boiler.

pressure of $20 \mathrm{~kg} \cdot \mathrm{cm}^{2}$ and a temperature of $280^{\circ} \mathrm{C}$. The gas is cooled in the boiler to approx. $180^{\circ} \mathrm{C}$, and is again sent to the quenching chamber by the main fan. Figure 2 shows the flow chart for the boiler, and Table 1 shows the design specifications of the main facilities of the NKK-Licensintorg C.D.Q. plant.

The main features of the NKK-Licensintorg C.D.Q. plant are as follows:

(1) Large capacity: To fully match the large capacity of the coke oven, the standard coke quenching capacity of $56 \mathrm{t} / \mathrm{hr}$ adopted in the USSR C.D.Q. system was increased to $70 \mathrm{t} / \mathrm{hr}$.

(2) Improvement of the operational efficiency of the C.D.Q. plant: The coke cars are automatically moved to the bottom of the crane tower directly by a turn table in order to minimize the idling time of the hoisting crane.

(3) Boiler: Instead of the power generator boiler $\left(40 \mathrm{~kg} / \mathrm{cm}^{2}, 490^{\circ} \mathrm{C}\right.$ ) used in the USSR, a low-pressure boiler for miscellaneous purposes $\left(20 \mathrm{~kg} / \mathrm{cm}^{2}, 280^{\circ} \mathrm{C}\right.$ ) was adopted.

(4) Gas circulating facility: To save power and stabilize operation, a constant temperature cascade control system based on the discharge gas temperature was adopted.

(5) Automation: To limit manual operation to supervisory functions, the coke cars, crane and other units were designed to operate automatically.

\section{Record of Steam Recovery Operation}

In order to effectively utilize the recovered steam, steam must be supplied at a stable rate, and the recovery efficiency of steam must be fully known. The results of the studies in this respect are given below.

\section{Stable Generation and Supply of Steam}

In order to be able to utilize the steam obtained in the C.D.Q. plant for miscellaneous purposes, a stable supply of steam must be secured in operation of the C.D.Q. plant. The prechamber has the most important function of stabilizing the steam generation to supply the boiler with stable heat by storing the redhot coke, absorbing time variations among pushing cycles. Each prechamber normally stores approx. $100 \mathrm{t}$ of red-hot coke. Figure 3 shows the trend of steam generation in the boiler. As can be seen, steam is normally generated at a stable rate.

\section{Heat Balance}

The heat balance calculation and the evaluation of steam recovery efficiency based on the comparison between the design specifications and the operational results are as follows. 
Table 1. Specifications of the C.D.Q. plant.

\begin{tabular}{|c|c|}
\hline Item & Rating \\
\hline Coke bucket & Effective volume: $75 \mathrm{~m}^{3}$ (with top cover), loading $29 \mathrm{t}$ \\
\hline Coke car & $\begin{array}{l}\text { Fully automatic two-axle bogie car. } \\
\text { Speed: } 200,60,10 \mathrm{~m} / \mathrm{min} \text {, usually } 2 \text { coke cars used. }\end{array}$ \\
\hline Over-head crane & $\begin{array}{l}\text { Fully automatic self-traveling crane. } \\
\text { Lifting load: } 80 \mathrm{t}, \text { Lifting speeds : } 35,20,10,3 \mathrm{~m} / \mathrm{min} \\
\text { Traveling speeds : } 60,3 \mathrm{~m} / \mathrm{min}\end{array}$ \\
\hline Charging device & Motor driven linkage type \\
\hline Quenching chamber & $\begin{array}{l}5 \text { sets, Capacity: } 70 \mathrm{t} / \mathrm{h} \text {, Prechamber volume : } 280 \mathrm{~m}^{3} / \mathrm{set} \\
\text { Quenching chamber volume : } 330 \mathrm{~m}^{3} / \mathrm{set}\end{array}$ \\
\hline Main fan & $\begin{array}{l}\text { Double suction radial fan. Air volume: } 105000 \mathrm{Nm}^{3} / \mathrm{H}, 730 \mathrm{mmAq} \text {. } \\
\text { Speed controlled by the circulating gas temperature, cascade control technique. }\end{array}$ \\
\hline Auxiliary fan & Single suction turbo-fan. Air volume: $43000 \mathrm{Nm}^{3} / \mathrm{H}, 20 \mathrm{~g} \mathrm{mmAq}$. \\
\hline Boiler & $\begin{array}{l}\text { Membrane wall type, Steam specifications : } 280^{\circ} \mathrm{C}, 20 \mathrm{~kg} / \mathrm{cm}^{2} \\
\text { Steam generation : } 38.5 \mathrm{t} / \mathrm{h} ; \text { Heat-transfer Area : } 1134 \mathrm{~m}^{2} \\
\text { Temperature of feed water: } 105^{\circ} \mathrm{C} \text { at the economizer inlet, } 180^{\circ} \mathrm{C} \text { at the boiler inlet }\end{array}$ \\
\hline Dust collector for circulating gas & $\begin{array}{l}\text { First stage: Dust settling chamber type } \\
\text { Second stage: Cyclone type }\end{array}$ \\
\hline Discharging device & Hydraulically driven type with a capacity of $5 \mathrm{~m}^{3} / \mathrm{min}$ \\
\hline Chamber top dust collector & Wet electrostatic precipitator with a capacity of $3000 \mathrm{~m}^{3} / \mathrm{min}$ \\
\hline Chamber bottom dust collector & Bag house with a capacity of $2000 \mathrm{~m}^{3} / \mathrm{min}$ \\
\hline Coke dust treatment & Suction type pneumatic transport system with a capacity of $6.5 \mathrm{t} / \mathrm{h}$ \\
\hline
\end{tabular}

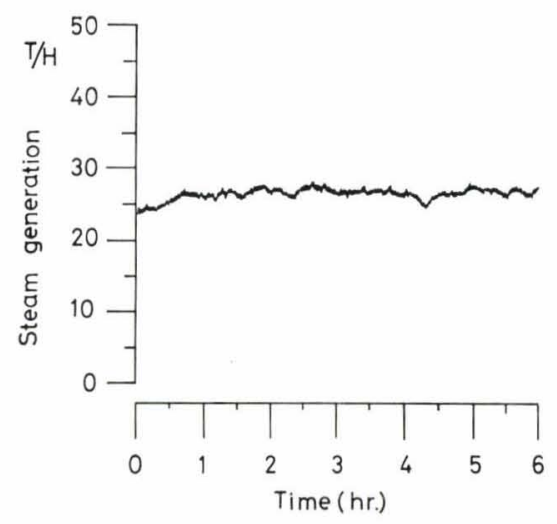

Fig. 3. Steam generation: variation with time.

\section{Heat Balance of C.D.Q. Plant}

The heat balance of the C.D.Q. plant operating under the conditions shown in Table 2 was calculated. Figure 4 shows the thermal flow in the C.D.Q. plant, Table 3 shows the heat balance of the C.D.Q. plant as a whole, and Table 4 shows the heat balance of the boiler only. Note that the heat of reaction in Table 3 in the inlet heat column mainly includes heat of combustion of the combustible components among the volatile matters released from the red-hot coke in the C.D.Q. plant, such as $\mathrm{H}_{2}$ and $\mathrm{CO}$, and also a small amount of heat of reaction resulting from the reactions $\mathrm{CO}_{2}+\mathrm{C} \rightarrow 2 \mathrm{CO}$ and $2 \mathrm{CO}+\mathrm{O}_{2} \rightarrow 2 \mathrm{CO}_{2}$. From this heat balance calculation, a recovery rate of the inlet heat to the C.D.Q. plant of $83.5 \%$ in the form
Table 2. Operational bases of the heat balance test.

\begin{tabular}{|c|c|}
\hline Item & Operational data \\
\hline Coke oven & $\begin{array}{l}\text { Working rate : } 104.8 \% \text { ( } 130 \text { pushes/d) } \\
\text { Flue temperature }: 1150^{\circ} \mathrm{C} \\
\text { Gross coking time }: 22 \mathrm{~h} 20 \mathrm{~min} \\
\text { Charge per oven }: 38.0 \mathrm{t} \text { (dry-base) } \\
\text { Coke per oven : } 29.0 \mathrm{t} \text { (dry-base) }\end{array}$ \\
\hline $\begin{array}{l}\text { Temperature and } \\
\text { volume of the } \\
\text { boiler inlet-gas }\end{array}$ & $\begin{array}{l}\text { Loading rate : } 96.4 \% \\
\text { Enthalpy of the inlet circulating gas: } \\
279.5 \mathrm{kcal} / \mathrm{Nm}^{3}\end{array}$ \\
\hline $\begin{array}{l}\text { Temperature of } \\
\text { the boiler } \\
\text { outlet gas }\end{array}$ & $\begin{array}{l}168^{\circ} \mathrm{C} \text {, Enthalpy of the outlet circulat- } \\
\text { ing gas: } 54 \mathrm{kcal} / \mathrm{Nm}^{3}\end{array}$ \\
\hline Steam generation & $\begin{array}{l}34.25 \mathrm{t} / \mathrm{h} \cdot \mathrm{set} \text {, pressure: } 13.8 \mathrm{~kg} / \mathrm{cm}^{2} \\
\text { Enthalpy of the steam : } 704.36 \mathrm{kcal} / \mathrm{Nm}^{3}\end{array}$ \\
\hline $\begin{array}{l}\text { Volume of the } \\
\text { continuous } \\
\text { blow-out water }\end{array}$ & $\begin{array}{l}2.24 \mathrm{t} / \mathrm{h} \text {, Enthalpy of the blow-out } \\
\text { water: } 204 \mathrm{kcal} / \mathrm{kg}\end{array}$ \\
\hline
\end{tabular}

of steam was confirmed. Table 4 shows a heat loss from the boiler wall of $2.0 \%$, which is considered to be reasonable for a waste heat recovery boiler of this type, in view of the high boiler loading rate of $96.4 \%$ during the test.

2. Comparison of Actual and Theoretical Steam Generation Rates

The actual steam generation rates under the conditions shown in Table 5 were compared with the 


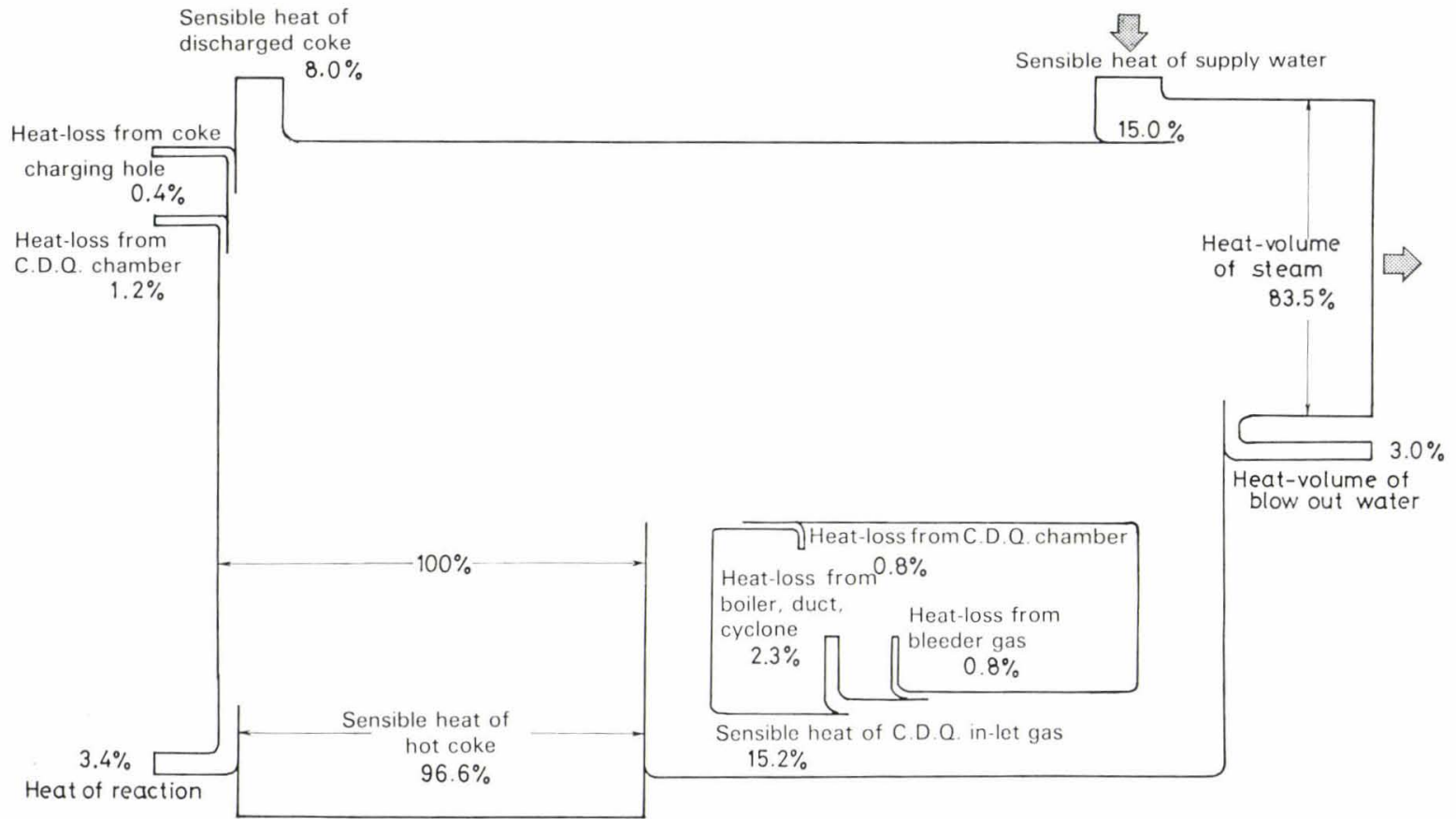

Fig. 4. Heat balance of C.D.Q. plant.

Table 3. Heat balance of the C.D.Q. plant.

\begin{tabular}{|c|c|c|c|}
\hline Input & $(\%)$ & Output & $(\%)$ \\
\hline $\begin{array}{l}\text { Sensible heat } \\
\text { of hot coke }\end{array}$ & 96.6 & $\begin{array}{l}\text { Sensible heat of discharged } \\
\text { coke }\end{array}$ & 8.0 \\
\hline \multirow[t]{5}{*}{$\begin{array}{l}\text { Heat of } \\
\text { reaction }\end{array}$} & \multirow[t]{5}{*}{3.4} & $\begin{array}{l}\text { Heat-loss from coke charging } \\
\text { hole }\end{array}$ & 0.4 \\
\hline & & Heat-volume of steam & 83.5 \\
\hline & & $\begin{array}{l}\text { Heat-volume of blow-out } \\
\text { water }\end{array}$ & 3.0 \\
\hline & & Heat-loss from bleeder gas & 0.8 \\
\hline & & $\begin{array}{l}\text { Heat-loss from C.D.Q. cham- } \\
\text { ber (Chamber wall, boiler, } \\
\text { duct and cyclone) }\end{array}$ & 4.3 \\
\hline Total & 100.0 & Total & 100.0 \\
\hline
\end{tabular}

Table 4. Heat balance of the boiler.

\begin{tabular}{|c|c|c|c|}
\hline Input & $(\%)$ & Output & $(\%)$ \\
\hline $\begin{array}{l}\text { Sensible heat of } \\
\text { circulating gas }\end{array}$ & 87.5 & Heat-volume of steam & 82.2 \\
\hline \multirow[t]{4}{*}{$\begin{array}{l}\text { Sensible heat of } \\
\text { supply water }\end{array}$} & 12.5 & $\begin{array}{l}\text { Heat-volume of the } \\
\text { blow-out water }\end{array}$ & 2.5 \\
\hline & & $\begin{array}{l}\text { Heat-loss from the } \\
\text { bleeder }\end{array}$ & 0.6 \\
\hline & & $\begin{array}{l}\text { Heat-loss from the boiler } \\
\text { wall }\end{array}$ & 2.0 \\
\hline & & $\begin{array}{l}\text { Sensible heat of the } \\
\text { circulating gas }\end{array}$ & 12.7 \\
\hline Total & 100.0 & Total & 100.0 \\
\hline
\end{tabular}

theoretical values resulting from the heat balance conditions obtained in the test. When the steam generation rate of the C.D.Q. plant was calculated for the conditions given in Table 5, $0.43 \mathrm{t} / \mathrm{t}$-coke and
Table 5. Basic calculation data of steam generation.

\begin{tabular}{|c|c|}
\hline Item & Basic condition \\
\hline $\begin{array}{l}\text { The temperature of the charging } \\
\text { hot coke }\end{array}$ & $950 \sim 1050^{\circ} \mathrm{C}$ \\
\hline Enthalpy of the charging hot coke & $350 \sim 395 \mathrm{kcal} / \mathrm{kg}$ \\
\hline Enthalpy of the steam & $700 \mathrm{kcal} / \mathrm{g}$ \\
\hline Heat-recovery rate of the steam & $83.5 \%$ \\
\hline Heat of reaction of inlet heat & $3.4 \%$ \\
\hline
\end{tabular}

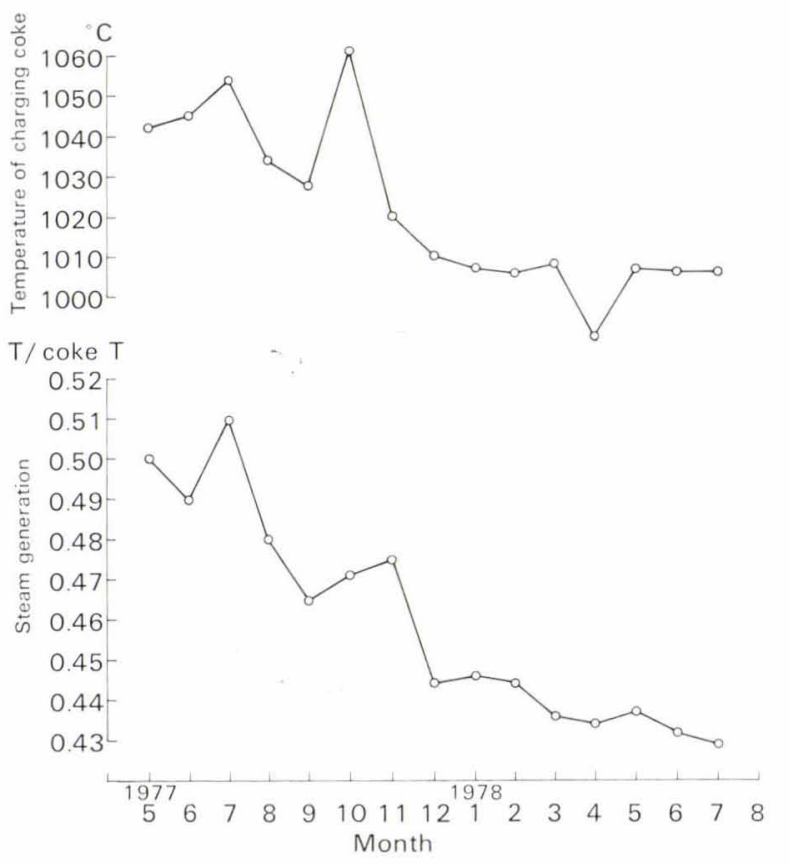

Fig. 5. Steam generation: monthly data. 
Table 6. Peculiarities of C.D.Q. boiler.

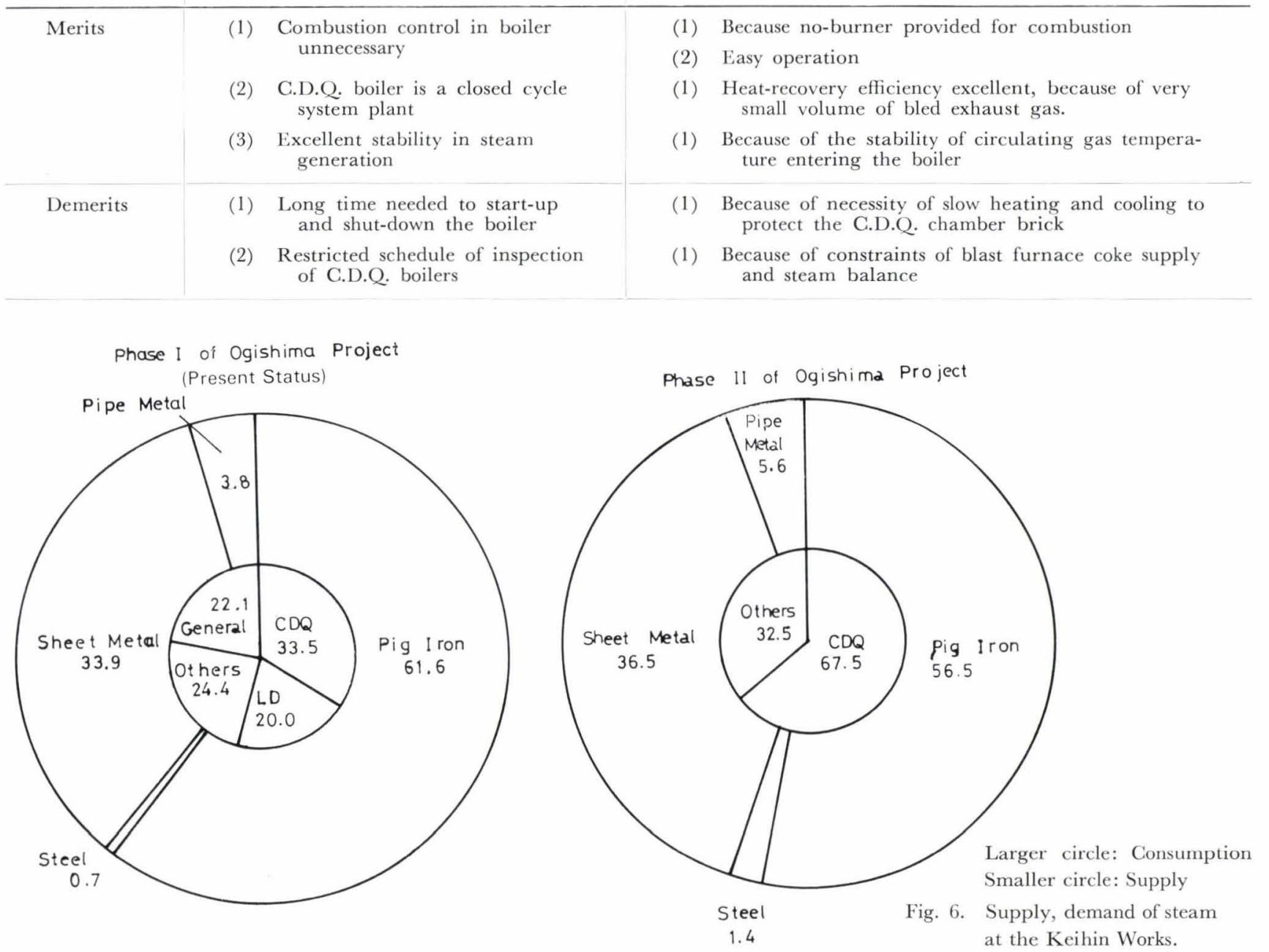

$0.49 \mathrm{t} / \mathrm{t}$-coke were obtained respectively for temperatures of the C.D.Q. charge coke of $950^{\circ}$ and $1050^{\circ}$ C. As can be seen from Fig. 5, which shows the actual steam generation rate for varying temperatures of hot charge coke, steam is actually gnerated at rates between 0.44 and $0.51 \mathrm{t} / \mathrm{t}$-coke, and the generating rate varies depending on the charge coke temperature and other operating methods and conditions.

As the generation and concentration of combustible gas in C.D.Q. plants are not desirable, from the viewpoint of controlling the composition of the circulating gas, coke ovens to which C.D.Q. plants are attached are operated with a soaking time longer than that of conventional coking ovens, and for this reason, the temperature of red-hot coke is a little higher than that from conventional coke ovens. The actual steam production data of the present C.D.Q. plant were found to be quite high in view of the levels specified by the licensor, Licensintorg of the USSR, 0.45 0.50 t/tcoke.

\section{Features and Cautions in C.D.Q. Boiler Op- eration}

As compared with conventional boilers having conventional burners, C.D.Q. boilers have the peculiarities shown in Table 6.
The possible influence of coke breeze contained in the circulating gas is naturally the prime consideration with the operation of the boiler.

\section{Influence of Dust Contained in Circulation Gas}

Needless to say, to reduce dust carried by the gas into the boiler which may be deposited on the heat transfer surfaces of the boiler tube, the boiler was designed with lower gas flow speed and larger gas duct crossection. To check the abrasion effect of the dust on the boiler tube, stainless steel protectors were attached to all the super heater tubes which make first contact with the incoming circulation gas, and the extent of abrasion of these protectors was measured when the boiler was opened for inspection. An abrasion of $0.2 \mathrm{~mm}$ of the wall thickness was measured. This value was considered to be not neglectable for a net service time of around one year, and dust abrasion is no doubt an important item demanding careful attention in operating the C.D.Q. plant in the future. However, all the tubes showed only very slight abrasion.

\section{Status of C.D.Q. Plants as Energy-saving Facilities in the NKK Keihin Works}

At present, the C.D.Q. steam accounts for $1.8 \%$ 


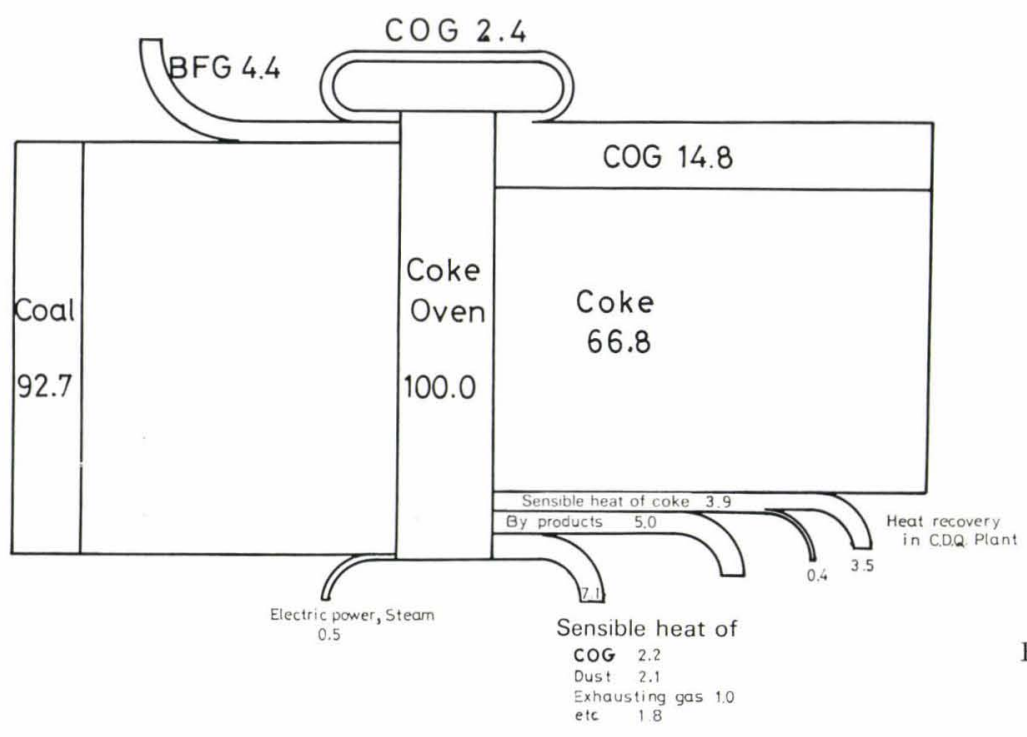

Fig. 7. Energy balance of the Ogishima coke oven. (Total energy demand for steelmaking: $5.2 \times$ $10^{6} \mathrm{kcal} / \mathrm{t}$-steel).

Table 7. Comparison between C.D.Q. coke and WET coke.

\begin{tabular}{|c|c|c|c|c|}
\hline & & C.D.Q. (A) & WET (B) & $\mathrm{A}-\mathrm{B}$ \\
\hline Moisture & $(\%)$ & 0 & 3 & $\triangle 3.0$ \\
\hline \multicolumn{5}{|l|}{ Coke Strength } \\
\hline$D I_{15}^{30}$ & $(\%)$ & 95.0 & 92.7 & 2.3 \\
\hline$D I_{15}^{30}$ & $(\%)$ & 65.7 & 41.0 & 24.7 \\
\hline$D I_{15}^{150}$ & $(\%)$ & 83.4 & 79.6 & 3.8 \\
\hline $\mathcal{N}_{25}$ & $*(\%)$ & 80.6 & 76.6 & 4.0 \\
\hline \multicolumn{5}{|l|}{ Reactivity } \\
\hline JIS & & 16.7 & 23.5 & $\triangle 6.8$ \\
\hline V.M. in coke & $(\%)$ & 0.42 & 0.75 & $\triangle 0.33$ \\
\hline Porosity & $(\%)$ & 46.8 & 50.7 & $\triangle 3.9$ \\
\hline \multicolumn{5}{|l|}{ Coke Size } \\
\hline Average size & $(\mathrm{mm})$ & 62.5 & 64.7 & $\triangle 2.2$ \\
\hline \multicolumn{5}{|l|}{ Size distribution } \\
\hline$+100 \mathrm{~mm}$ & & 4.9 & 7.9 & $\triangle 3.0$ \\
\hline+75 & & 21.8 & 25.0 & $\triangle 3.2$ \\
\hline+50 & & 40.0 & 40.9 & $\triangle 0.9$ \\
\hline+38 & & 23.1 & 16.2 & 6.9 \\
\hline+25 & & 7.8 & 5.3 & 2.5 \\
\hline-25 & & 2.4 & 4.7 & $\triangle 2.3$ \\
\hline
\end{tabular}

* Coke strength after heat treatment at $1500^{\circ} \mathrm{C}$.

of total energy consumed at the Keihin Works, and the figure will rise to $2.7 \%$ when the Stage 2 work of the Ogishima Project has been completed. In terms of the steam balance at the Keihin Works, the C.D.Q. steam accounts for approx. $30 \%$ at present and will account for nearly $70 \%$ after completion of Stage 2 (Fig. 6). When a C.D.Q. plant is incorporated in the energy balance scheme of a steel works from the planning stage, as in the present case, it can contribute materially to the energy-saving scheme of a steel works. An energy flow diagram of the Ogishima coke oven (as at completion of Stage 2 work) is shown in Fig. 7 for reference.

\section{Coke Quality Improvement}

So far, the energy-saving effect of the C.D.Q. plant has been definitely confirmed, but since a coke oven of a steel works is operated for the sole purpose of producing coke to be used in blast furnaces, the influence of C.D.Q. plants on the coke quality is an important matter.

As shown in Table 7, the survey results up to now have revealed that the coke quenched in the C.D.Q. plant has better strength, reactivity, and other qualities. These improvements are considered to be due to the very much slower cooling rate of coke in the C.D.Q. plant compared with that from the water spray quenching process. This means that C.D.Q. process can save the expensive good coking coal required for producing excellent metallurgical coke. This result makes the C.D.Q. plant also a valuable resources-saving facility, not only an energy-saving facility.

\section{Conclusion}

The coke dry quenching unit at Ogishima Works was built by NKK under license from Licensintorg of the USSR and a number of modifications which are described herein have been introduced into this unit. The plant has been operating very smoothly, fully proving its energy-saving performance, and its important role as a steam generating facility. In addition to this, improvements were also observed in coke qualities after processing in the C.D.Q. plant. In view of the fact that coke ovens of a steel works are operated for the sole purpose of producing coke to be used in blast furnaces, this is an important factor contributing towards the stable operation of blast furnaces. It is hoped that with further refinement of the technology, the energy-saving and resources-saving values of the C.D.Q. system will be further increased. The C.D.Q. plant under construction for the 2nd coke oven is expected to show better performance than those of the present plant, by the full utilization of the experience gained in the latter. 